\title{
Acute Lower Respiratory Tract Infection
}

\author{
Joseph P. Mizgerd, Sc.D. \\ From the Molecular and Integrative Physiological Sciences Program, Harvard School of Public \\ Health, Boston.
}

Acute lower respiratory tract infections are a persistent and pervasive public health problem. They cause a greater burden of disease worldwide than human immunodeficiency virus infection, malaria, cancer, or heart attacks. ${ }^{1}$ In the United States, they cause more disease and death than any other infection, and there has been little change in mortality due to respiratory tract infection for more than five decades. ${ }^{1,2}$ The outcome of an acute lower respiratory tract infection depends on the virulence of the organism and the inflammatory response in the lung. When small numbers of low-virulence microbes are deposited in the lungs, an effective defense can be mounted by resident innate immune defenses, such as the mucociliary escalator, antimicrobial proteins in airway surface liquid, and alveolar macrophages. In contrast, numerous or more virulent microbes elicit an inflammatory response. Although this response serves to reinforce innate immunity and is essential to rid the lungs of microbes, it contributes directly to lung injury and abnormal pulmonary function. This article reviews our current understanding of inflammatory responses in infected lungs, emphasizing recent advances and gaps in knowledge. Much of the information originates from animal experiments; studies with human volunteers and patient-derived data are included when appropriate and available.

\section{INFLAMMATION AND INNATE IMMUNITY}

Acute inflammation features the accumulation of neutrophils and a plasma exudate outside of blood vessels. In the pulmonary capillaries of uninfected lungs, these blood contents are normally separated from the alveolar air by less than $1 \mu \mathrm{m}$, the thinnest interface between the blood and the environment. The trapping of neutrophils in these capillaries, which is the result of geometric and biophysical constraints, ${ }^{3}$ increases their quantity per volume of blood by approximately 50 times as compared with other blood vessels, forming a marginated pool of neutrophils that is ready to respond when needed.

During pulmonary infection, neutrophils migrate out of the pulmonary capillaries and into the air spaces. ${ }^{4}$ Elie Metchnikoff, the discoverer of phagocytosis, considered neutrophils (or microphages, as he called them) to be "the defensive cells par excellence against microorganisms." 5 After phagocytosis, neutrophils kill ingested microbes with reactive oxygen species (e.g., hypochlorite), antimicrobial proteins (e.g., bactericidal permeabilityinducing protein and lactoferrin), and degradative enzymes (e.g., elastase) (Fig. 1). ${ }^{6}$ An additional microbicidal pathway has also been identified - the neutrophil extracellular trap (NET). Neutrophils extrude NETs composed of a chromatin meshwork containing antimicrobial proteins, and these NETs ensnare and kill extracellular bacteria. ${ }^{7}$ It remains to be determined whether NETs are useful host defense mechanisms against motile microbes in the dynamic and unstructured liquid-filled air spaces of the infected lung.

Copyright @ 2008 Massachusetts Medical Society.

Address reprint requests to Dr. Mizgerd at Molecular and Integrative Physiological Sciences, Harvard School of Public Health, 665 Huntington Ave., Boston, MA 02115, or at E-mail: jmizgerd@hsph.harvard.edu. 
The content of plasma proteins in the interstitium and air spaces of infected lungs is determined by the combined actions of pericellular bulk flow and transcellular transport by endothelial and epithelial cells. Many plasma proteins, including natural antibodies, complement proteins, C-reactive protein (originally identified in serum from patients with pneumonia ${ }^{8}$ ), and pentraxin 3 , are important for the defense against microbes in the lungs. ${ }^{9-13}$ They serve opsonic, bacteriostatic, and microbicidal functions during infection.

Deficits in neutrophil quantity (neutropenia) and defects in quality (e.g., chronic granulomatous disease) predispose patients to opportunistic lung infections, as do deficiencies of complement and immunoglobulins. Since neutrophils and plasma proteins mediate innate immune functions and are needed to prevent lung infection, acute inflammation can be considered an essential innate immune response in the lungs.

\section{GENERATION OF ACUTE INFLAMMATION IN INFECTED LUNGS MOLECULES THAT DETECT MICROBES}

Microbes must be detected by host cells to initiate inflammation in infected lungs. The identification of microbial invaders relies on a set of diverse receptors called patternrecognition receptors, which bind molecular moieties that are common to microbes. ${ }^{14}$ Discoveries of new families of pattern-recognition receptors, including toll-like receptors, nucleotide-binding and oligomerization-domain proteins, and caspase-recruitment domain helicases, have fueled research in the biology of innate immunity. Table 1 lists some of the pattern-recognition receptors with direct relevance to innate immunity in the lungs or to respiratory infection.

For any one microbe, there are a variety of molecules that can activate many different patternrecognition receptors. Perhaps for this reason, deficiencies of individual pattern-recognition receptors result in more modest phenotypes during experimentally induced acute lower respiratory infections than deficiencies of downstream adapter proteins, which signal from multiple pattern-recognition receptors. ${ }^{41,42}$ The intracellular signaling pathways triggered by diverse pattern-recognition receptors converge on signaling hubs, such as transcription factors of the nuclear factor $\kappa \mathrm{B}(\mathrm{NF}-\mathrm{\kappa B})$ and interferon regulatory factor families. These factors integrate signals from diverse stimuli (interacting with pattern-recognition receptors) and initiate responses. NF- $\mathrm{kB}$ mediates the transcription of adhesion molecules, chemokines, colony-stimulating factors, and other cytokines that are necessary for inflammatory responses. 43 In mice with bacterial stimuli in the lungs, NF- $\mathrm{kB}$ RelA (also known as p65) is required for inducing the production of adhesion molecules and chemokines as well as for initiating neutrophil recruitment and host defense. ${ }^{44,45}$ Interferon regulatory factors mediate the expression of type I interferons and interferon-induced antiviral genes. ${ }^{46}$ Interferon regulatory factor 3 influences parainfluenza virus infection in mouse lungs, ${ }^{47}$ but the genes and immune functions that require it or other interferon regulatory factors during lung infection remain unknown.

\section{SENTINEL CELLS IN THE LUNGS}

Populations of myeloid cells with specialized functions as sentinels, the alveolar macrophages and dendritic cells, reside in the lungs. These cells are particularly well equipped with patternrecognition receptors and are anatomically situated to encounter microbes in the air spaces.

Alveolar macrophages are mobile cells that patrol the luminal surfaces of the alveoli. They have been referred to as dust cells because of their abilities to remove and digest relatively inert inhaled materials. They are also sources of alarm signals when lungs are infected, but inhibition of these signals until the appropriate time is imperative. One possible inhibitory mechanism entails the globular heads of surfactant proteins A and D, which bind alveolar- 
macrophage receptors and suppress inflammatory activity in uninfected lungs. During infection, these globular heads bind pathogens, and the presentation of oligomerized collagenous tails (a result of the clustering of the surfactant proteins on pathogen surfaces) activates rather than quiets alveolar macrophages. ${ }^{48}$ It is plausible that the inflammatory activity of alveolar macrophages is constitutively suppressed by transforming growth factor $\beta$, which is presented to them by epithelial-cell integrins; microbial products initiate signaling that interferes with this suppression, thereby activating the inflammatory functions of alveolar macrophages. 49

Dendritic cells are distributed throughout the respiratory tract. In the conducting airways, intraepithelial dendritic cells extend into the fluid within the airway lumen, where they ingest samples from the materials being swept by mucociliary transport from the alveoli toward the glottis. ${ }^{50}$ In response to the presence of microbes in the lungs, more dendritic cells migrate into the lungs, through the tissues, and also into the draining lymph nodes. ${ }^{50}$ Dendritic cells are antigen-presenting cells and are therefore central to adaptive immune responses. They also have important functions in innate immunity. Their pattern-recognition receptors render them especially suited to detecting viruses, and when stimulated they produce very high levels of type I interferons. ${ }^{51}$ The depletion of dendritic cells or the interruption of type I interferon signaling increases susceptibility to viruses in the lungs. 52,53

Alveolar macrophages and dendritic cells have a limited ability to kill microbes, but they are particularly important for sensing microbes and passing this information along to other cells, such as epithelial cells and lymphocytes. These cells then recruit the effectors of innate immunity, neutrophils.

\section{EFFECTORS OF INNATE IMMUNITY}

Neutrophil recruitment is directed by lung cells. Adhesion molecules induced on lung cells provide traction and signaling information to neutrophils. ${ }^{54}$ Chemokines from lung cells stimulate chemotaxis and influence the directional motility of neutrophils. 54 Colonystimulating factors signal neutrophil production and release from hematopoietic tissues. 55

The epithelial barrier between the air-space content of the lungs (including microbes) and the rest of the body constitutes a critical interface for information transfer leading to neutrophil recruitment (Fig. 2). In transgenic mice in which an inhibitor of NF- $\kappa \mathrm{B}$ activation is expressed exclusively in lung epithelial cells, the interruption of NF- $\kappa \mathrm{B}$ activation decreases the expression of cytokines, including neutrophil chemokines. 56,57 This defect in epithelial-cell gene expression compromises neutrophil recruitment and bacterial killing in the lungs. 45,56 , 57

With the increasing recognition of the roles of epithelial cells in lung inflammatory responses, 58 efforts are under way to illuminate the pathways of epithelial-cell activation in infected lungs. Lung epithelial cells can be activated directly by some microbes, such as Staphylococcus aureus and Pseudomonas aeruginosa. ${ }^{59,60}$ However, other microbes, such as pneumococci (the most common cause of community-acquired pneumonia), are less likely to be or cannot be recognized by epithelial cells. ${ }^{45}$ During pneumococcal pneumonia, alarm signals generated by sentinel myeloid cells, particularly tumor necrosis factor $\alpha$ (TNF- $\alpha)$ and interleukin-1 ( $1 \alpha$ and $1 \beta$ ), are essential for activation of the epithelium and downstream inflammatory responses. 45,61 Blocking the signaling of either TNF- $\alpha$ or interleukin-1 produces modest effects as compared with blocking both pathways simultaneously, ${ }^{61-63}$ suggesting that these cytokines have overlapping functions during acute respiratory tract infection. Neutrophil-mediated host defense against pneumococci in the lungs requires such signaling. 
Epithelial cells can also be activated by lymphocyte cytokines (Fig. 2). Interleukin-17 activates lung epithelial cells to express chemokines and colony-stimulating factors, and it is essential for neutrophil-mediated host defense during klebsiella pneumonia. ${ }^{64}$ During such infection, interleukin-17 is produced by T cells, and its production is stimulated by another signal from macrophages - interleukin-23. ${ }^{65} \mathrm{~A}$ subpopulation of invariant natural killer T cells in the lungs can also generate interleukin-17 to stimulate epithelial cells and elicit neutrophil recruitment, and the interleukin-17 expressed by these cells may not depend on interleukin-23. ${ }^{66}$ Interleukin-17-secreting T cells also release interleukin-22, which functions like interleukin-17 in activating epithelial cells. ${ }^{67}$ If, when, and how interleukin-22 influences innate immune responses during lung infection are questions yet to be answered.

Neutrophils are not dead ends in these communication pathways but convey important information that directs immune responses (Fig. 1). ${ }^{6}$ They generate proinflammatory signals, including TNF- $\alpha$, interleukin-1, and chemokines; chemerin, which recruits and activates dendritic cells; and B-lymphocyte stimulator, which promotes the selection, survival, and growth of B cells. Neutrophils are sources of the T-cell-activating cytokine interleukin-12 in the lungs, 68 and interleukin-12 amplifies interferon- $\gamma$ to enhance neutrophil-mediated host defense during pneumonia. ${ }^{69}$ Neutrophils constitutively express the extracellular patternrecognition receptor pentraxin 3 , and the compromised host defense of mice with pentraxin 3 deficiency can be improved by the administration of soluble pentraxin 3 or by transfer of neutrophils from wild-type but not pentraxin 3 -deficient mice. ${ }^{10,70}$ Thus, acquired and innate immune responses against microbes in the lungs are shaped by signals derived from neutrophils.

\section{INFLAMMATION AND ACUTE LUNG INJURY}

Inflammation is critical for innate immunity and host defense, but it can injure the lungs. The accumulation of extravascular plasma fluids, as in noncardiogenic pulmonary edema, is a defining feature of acute lung injury. The neutrophil products generated to kill microbes, such as reactive oxygen species and proteases, also kill host cells and damage host tissues (Fig. 1). The risks of inflammation are starkly demonstrated in a transgenic mouse model in which the activation of NF-kB in lung epithelial cells is sufficient to cause neutrophil recruitment, pulmonary edema, arterial hypoxemia, and death in the absence of any infection or exogenous stimuli. ${ }^{71}$ Thus, the innate immune responses necessary for ridding the lungs of microbes can also cause injury and contribute to the pathophysiology of infection. Perhaps because of this, lung infection is a common underlying cause of the acute respiratory distress syndrome. 72

Inhibiting inflammatory signals can be protective during lung infections. For example, interrupting both TNF- $\alpha$ and interleukin-1 signaling (but neither alone) decreases the pulmonary edema and the loss of lung compliance that are often found in mice with Escherichia coli pneumonia. ${ }^{62,63}$ Triggering receptor expressed on myeloid cells 1 (TREM-1), which functions in a positive feedback loop to amplify TNF- $\alpha$, interleukin-1, and inflammation, 73 is so strongly associated with pneumonia in patients that measurement of soluble TREM- 1 in bronchoalveolar-lavage fluid has been proposed as a diagnostic test. ${ }^{74}$ Inhibition of TREM-1 diminishes TNF, interleukin-1, and pathophysiological features in rats with $P$. aeruginosa pneumonia. ${ }^{75}$ Corticosteroids can be effective albeit nonspecific inhibitors of inflammation. In a clinical trial of corticosteroid infusion in patients with severe community-acquired pneumonia, the 23 patients in the corticosteroid group had less lung injury and a higher rate of survival than the 23 patients in the placebo group. ${ }^{76}$ Results from this small study are provocative but must be viewed with caution until further studies are completed. ${ }^{77}$ Knowledge gaps remain substantial. It is not yet evident which patients with which infections may benefit from which antiinflammatory therapies at which times. Altogether, however, these studies 
suggest that inflammation-targeting therapies may be useful in treating certain severe lung infections, encouraging further research along these lines.

Highly pathogenic influenza viruses, such as avian influenza A (H5N1) virus and the virus causing the 1918 pandemic, induce strong inflammatory responses in humans and laboratory animals. ${ }^{78,79}$ The seemingly excessive responses bolster the idea that a so-called cytokine storm mediates pathophysiology during these infections, but direct evidence in support of this concept is scant. Neutrophil depletion increases viral growth and hastens death in mice infected with the $\mathrm{H} 5 \mathrm{~N} 1$ influenza A virus, ${ }^{80}$ suggesting that at least in this experimental infection, neutrophils do more good than harm. Interruptions of cytokine signaling in mice with H5N1 influenza A virus infections have modest or no effects, ${ }^{81}$ suggesting that the cytokines so far examined are not individually essential to the pathophysiology of H5N1 influenza virus infection. Further studies will be critical in determining whether and, if so, which inflammatory mediators influence the pathophysiology of highly pathogenic influenza virus infections, and whether the interruption of select cytokines or signaling pathways upstream or downstream from cytokines can protect the host from inflammatory injury during such infections.

\section{REGULATION OF ACUTE INFLAMMATION IN INFECTED LUNGS}

The body needs mechanisms to keep acute inflammation in check. Much less is known about these regulatory mechanisms than about the mechanisms initiating and amplifying inflammation. A few examples of how regulatory mechanisms influence the outcome of lung infections are presented here.

One such braking strategy is to limit NF- $\mathrm{BB}$ activity. The NF- $\mathrm{KB}$ protein $\mathrm{p} 50$ has multiple functions, which include curbing the transcription of genes with NF- $\mathrm{KB}$-binding sites in their promoters. ${ }^{43}$ During bacterial pneumonia in mice, a deficiency of p50 increases cytokine expression and exacerbates lung injury. ${ }^{82}$ Thus, p50 normally functions to prevent excess cytokines and inflammatory injury during pneumonia.

Another mechanism is interference with signaling from pattern-recognition receptors. The interleukin-1 receptor-associated kinase (IRAK)-like molecule (IRAK-M) inhibits IRAKmediated signaling from the pattern-recognition and cytokine receptors that activate NF- $\mathrm{\kappa B}$. Sepsis induces IRAK-M in mouse alveolar macrophages, and this protein decreases cytokine expression and compromises pulmonary host defense. ${ }^{83}$ IRAK-M may therefore contribute to the susceptibility of patients with sepsis to nosocomial pneumonia. Other regulatory molecules inhibit pattern-recognition-receptor signaling indirectly. For example, carbon monoxide generated by heme oxygenase- 1 inhibits signaling from transmembrane pattern-recognition receptors. ${ }^{84}$ A deficiency of heme oxygenase-1 increases, whereas its overexpression decreases, inflammation and injury induced by bacteria and influenza virus in mouse lungs. 85-87 Prevention of injury is probably due to both the antiinflammatory and the tissueprotective activities of heme oxygenase-1.

The signal transducer and activator of transcription 3 (STAT3) also has antiinflammatory and tissue-protective effects. Mutations in STAT3 result in the hyper-IgE syndrome, which is characterized by recurrent and severe lung infections. ${ }^{88}$ This transcription factor is activated in macrophages and epithelial cells during acute pulmonary inflammation. ${ }^{89}$ Macrophage STAT3 mediates antiinflammatory responses induced by the cytokine interleukin-10, 90 which compromises host defense but limits lung injury during pneumonia. ${ }^{91-94}$ Epithelial-cell STAT3 is essential in preventing lung injury during infection. ${ }^{95}$ The signals that activate epithelial-cell STAT3 are uncertain, but are not likely to include interleukin-10. STAT3 activation in the lungs during $E$. coli infection depends partially on interleukin-6, which is essential for overcoming bacterial pneumonia. 96 
Prostaglandin $I_{2}$ (prostacyclin) is generated during respiratory syncytial virus infection and has protective activities that may be mediated by antiinflammatory effects on dendritic cells. 97 ,

98 In addition to having antiinflammatory activities, other lipids, including lipoxins, resolvins, and protectins, help return inflamed tissues to health. ${ }^{99}$ During and after pneumonia, the return of the architecture of a lung lobe from complete consolidation to a seemingly normal state is remarkable. Unfortunately, few if any studies have reported the mechanisms underlying this process of resolution during lung infection, so the presumed role of lipids must at present be based on extrapolation.

\section{RESPONSES OF MICROBES TO INFLAMMATION}

Acute lower respiratory tract infections can be monomicrobial or polymicrobial, with organisms ranging in virulence from commensal to highly pathogenic. ${ }^{100-102}$ These microbes have mechanisms for counteracting many of the effector and signaling events described above. Microbial subversion of individual pathways may be a selective pressure driving mammalian hosts to have multiple, parallel, sometimes redundant-seeming pathways for innate immunity, as with epithelial activation (Fig. 2). A few microbial strategies specifically related to lung infections and the pathways of innate immunity described above are highlighted here as examples.

Counteracting effector mechanisms of innate immunity is of obvious advantage to a microbe. Although NETs were discovered only recently, ${ }^{7}$ microbial countermeasures are already recognized. For example, NETs extruded by neutrophils fail to contain and kill pneumococci. 103 A pneumococcal DNase cleaves NETs and frees bacteria. During infection, this DNase is a virulence factor that gives the bacteria a competitive advantage against DNase-mutated strains in the lungs of mice, resulting in increased mortality from pneumonia in such mice.

Preventing the host from detecting pathogens is another strategy often used by microbes. For example, the retinoic acid-inducible gene I intracellular pattern-recognition receptor for viral RNA is bound by an influenza virus protein that prevents downstream signaling, activation of interferon regulatory factor, and expression of type I interferon. ${ }^{104}$ Deleting this protein attenuates influenza virus infection, increasing type I interferon in the lungs and decreasing mortality. ${ }^{105}$ Many pathogens interrupt proinflammatory signaling pathways or mimic antiinflammatory signaling pathways.

Not only do lung pathogens interfere with host signaling, they also listen in on these immune conversations and use this information to guide their responses appropriately. For example, $P$. aeruginosa expresses a receptor that recognizes interferon- $\gamma$, and in the presence of interferon$\gamma$, this receptor stimulates gene expression dictating biofilm formation. ${ }^{106}$ Since biofilms render bacteria more resistant to both innate immunity and antibiotics, this is probably an adaptive response during infection. In addition, $P$. aeruginos $a$ and other bacteria respond to TNF- $\alpha$ and other cytokines with increased growth rates. ${ }^{107}$ In neutropenic mice, the ability of TNF- $\alpha$ to increase bacterial growth worsens lung infection. ${ }^{108}$ Thus, pathogens sense innate immune signaling and respond in ways that subvert host defense and facilitate infection.

\section{GENETIC VARIATION IN INFLAMMATORY PATHWAYS}

The mechanisms for generating and regulating acute inflammation, described above, determine the outcomes of experimentally induced lung infections in animals. Deficiencies and polymorphisms in human genes for the factors involved in these mechanisms have been associated with lung infection and its consequences, such as disseminated or invasive infection or acute lung injury (Table 2). Although the limitations of such genotype-phenotype associations warrant consideration, ${ }^{129}$ these data indicate that knowledge of innate immunity and lung infection derived from experiments in animals can apply to humans. Genetic 
variations in innate-immunity mediators influence the outcome of inevitable exposures of the human lower respiratory tract to microbes.

Another reason why human genotype-phenotype studies are important is that they occur in natural instead of laboratory environments. Infections involve intersections of host and microbe within complex and dynamic ecosystems not mimicked in laboratory studies. For example, patients with a deficiency of IRAK-4 (which signals from multiple pattern-recognition receptors) are susceptible to a narrower spectrum of microbes, over a narrower age range, and with more variation across the population than in vitro experiments with human cells or in vivo experiments with mice would suggest. ${ }^{113}$ Patients with an immunodeficiency tend to present with select subgroups of infections (e.g., patients with chronic granulomatous disease are especially susceptible to five microbes ${ }^{130}$ ). Environmental and genomic variations result in a range of susceptibility among patients with similar immunodeficiencies. In the future, polygenic analyses may demonstrate that combined polymorphisms in multiple genes influence lung infections more dramatically than monogenic variation, since parallel paths and redundancies are common in innate immunity. An emerging theme is that genetic susceptibility to infection is more common than is now appreciated; susceptibility is probably polygenic, with incomplete penetrance restricted to narrowly defined clinical phenotypes. ${ }^{131}$

\section{Conclusions}

Innate immune responses to microbes in the lungs determine the outcome of infection; an insufficient response can result in life-threatening infection, but an excessive response can lead to life-threatening inflammatory injury. Further studies will help identify populations that are particularly susceptible to severe lung infection and will guide the development of prophylactic and therapeutic interventions.

\section{Acknowledgments}

Supported by grants from the National Institutes of Health (HL-68153 and HL-79392).

Dr. Mizgerd reports receiving consulting fees from Sirtris Pharmaceuticals and ImmunoGen and receiving pilot-study funding from Pulmatrix. No other potential conflict of interest relevant to this article was reported.

I thank Drs. Lester Kobzik and Mark Perrella, as well as members of the laboratory, for helpful critiques and suggestions concerning this article.

\section{References}

1. Mizgerd JP. Lung infection — a public health priority. PLoS Med 2006;3(2):e76. [PubMed: 16401173]

2. Armstrong GL, Conn LA, Pinner RW. Trends in infectious disease mortality in the United States during the 20th century. JAMA 1999;281:61-66. [PubMed: 9892452]

3. Doerschuk CM. Mechanisms of leukocyte sequestration in inflamed lungs. Microcirculation 2001;8:71-88. [PubMed: 11379793]

4. Burns AR, Smith CW, Walker DC. Unique structural features that influence neutrophil emigration into the lung. Physiol Rev 2003;83:309-336. [PubMed: 12663861]

5. Metchnikoff, E., editor. Immunity in infective diseases. London: Cambridge University Press; 1905. The mechanism of natural immunity against micro-organisms; p. 175-206.

6. Nathan C. Neutrophils and immunity: challenges and opportunities. Nat Rev Immunol 2006;6:173182. [PubMed: 16498448]

7. Brinkmann V, Reichard U, Goosmann C, et al. Neutrophil extracellular traps kill bacteria. Science 2004;303:1532-1535. [PubMed: 15001782]

8. Tillett WS, Francis T Jr. Serological reactions in pneumonia with a non-protein somatic fraction of pneumococcus. J Exp Med 1930;52:561-571. 
9. Kopf M, Abel B, Gallimore A, Carroll M, Bachmann MF. Complement component C3 promotes Tcell priming and lung migration to control acute influenza virus infection. Nat Med 2002;8:373-378. [PubMed: 11927943]

10. Garlanda C, Hirsch E, Bozza S, et al. Non-redundant role of the long pentraxin PTX3 in anti-fungal innate immune response. Nature 2002;420:182-186. [PubMed: 12432394]

11. Mold C, Rodic-Polic B, Du Clos TW. Protection from Streptococcus pneumoniae infection by Creactive protein and natural antibody requires complement but not $\mathrm{Fc}$ gamma receptors. J Immunol 2002;168:6375-6381. [PubMed: 12055255]

12. Mueller-Ortiz SL, Drouin SM, Wetsel RA. The alternative activation pathway and complement component $\mathrm{C} 3$ are critical for a protective immune response against Pseudomonas aeruginosa in a murine model of pneumonia. Infect Immun 2004;72:2899-2906. [PubMed: 15102802]

13. Jayasekera JP, Moseman EA, Carroll MC. Natural antibody and complement mediate neutralization of influenza virus in the absence of prior immunity. J Virol 2007;81:3487-3494. [PubMed: 17202212]

14. Akira S, Uematsu S, Takeuchi O. Pathogen recognition and innate immunity. Cell 2006;124:783801. [PubMed: 16497588]

15. Knapp S, Wieland CW, van 't Veer C, et al. Toll-like receptor 2 plays a role in the early inflammatory response to murine pneumococcal pneumonia but does not contribute to antibacterial defense. J Immunol 2004;172:3132-3138. [PubMed: 14978119]

16. Rudd BD, Smit JJ, Flavell RA, et al. Deletion of TLR3 alters the pulmonary immune environment and mucus production during respiratory syncytial virus infection. J Immunol 2006;176:1937-1942. [PubMed: 16424225]

17. Branger J, Knapp S, Weijer S, et al. Role of Toll-like receptor 4 in gram-positive and gram-negative pneumonia in mice. Infect Immun 2004;72:788-794. [PubMed: 14742522]

18. Kurt-Jones EA, Popova L, Kwinn L, et al. Pattern recognition receptors TLR4 and CD14 mediate response to respiratory syncytial virus. Nat Immunol 2000;1:398-401. [PubMed: 11062499]

19. Malley R, Henneke P, Morse SC, et al. Recognition of pneumolysin by Toll-like receptor 4 confers resistance to pneumococcal infection. Proc Natl Acad Sci U S A 2003;100:1966-1971. [PubMed: 12569171]

20. Feuillet V, Medjane S, Mondor I, et al. Involvement of Toll-like receptor 5 in the recognition of flagellated bacteria. Proc Natl Acad Sci U S A 2006;103:12487-12492. [PubMed: 16891416]

21. Albiger B, Dahlberg S, Sandgren A, et al. Toll-like receptor 9 acts at an early stage in host defence against pneumococcal infection. Cell Microbiol 2007;9:633-644. [PubMed: 17004992]

22. Arredouani M, Yang Z, Ning Y, et al. The scavenger receptor MARCO is required for lung defense against pneumococcal pneumonia and inhaled particles. J Exp Med 2004;200:267-272. [PubMed: 15263032]

23. Arredouani MS, Yang Z, Imrich A, Ning Y, Qin G, Kobzik L. The macrophage scavenger receptor SR-AI/II and lung defense against pneumococci and particles. Am J Respir Cell Mol Biol 2006;35:474-478. [PubMed: 16675784]

24. Steele C, Marrero L, Swain S, et al. Alveolar macrophage-mediated killing of Pneumocystis carinii f. sp. muris involves molecular recognition by the Dectin-1 beta-glucan receptor. J Exp Med 2003;198:1677-1688. [PubMed: 14657220]

25. Steele C, Rapaka RR, Metz A, et al. The beta-glucan receptor dectin-1 recognizes specific morphologies of Aspergillus fumigatus. PLoS Pathog 2005;1(4):e42. [PubMed: 16344862]

26. Koppel EA, Wieland CW, van den Berg VC, et al. Specific ICAM-3 grabbing nonintegrin-related 1 (SIGNR1) expressed by marginal zone macrophages is essential for defense against pulmonary Streptococcus pneumoniae infection. Eur J Immunol 2005;35:2962-2969. [PubMed: 16134084]

27. Fillion I, Ouellet N, Simard M, Bergeron Y, Sato S, Bergeron MG. Role of chemokines and formyl peptides in pneumococcal pneumonia-induced monocyte/macrophage recruitment. J Immunol 2001;166:7353-7361. [PubMed: 11390486]

28. Tachado SD, Zhang J, Zhu J, Patel N, Cushion M, Koziel H. Pneumocystis-mediated IL-8 release by macrophages requires coexpression of mannose receptors and TLR2. J Leukoc Biol 2007;81:205211. [PubMed: 17020928] 
29. Mandelboim O, Lieberman N, Lev M, et al. Recognition of haemagglutinins on virus-infected cells by NKp46 activates lysis by human NK cells. Nature 2001;409:1055-1060. [PubMed: 11234016]

30. Gazit R, Gruda R, Elboim M, et al. Lethal influenza infection in the absence of the natural killer cell receptor gene Ncr1. Nat Immunol 2006;7:517-523. [PubMed: 16565719]

31. Wright EK, Goodart SA, Growney JD, et al. Naip5 affects host susceptibility to the intracellular pathogen Legionella pneumophila. Curr Biol 2003;13:27-36. [PubMed: 12526741]

32. Amer A, Franchi L, Kanneganti TD, et al. Regulation of Legionella phagosome maturation and infection through flagellin and host Ipaf. J Biol Chem 2006;281:35217-35223. [PubMed: 16984919]

33. Opitz B, Püschel A, Schmeck B, et al. Nucleotide-binding oligomerization domain proteins are innate immune receptors for internalized Streptococcus pneumoniae. J Biol Chem 2004;279:36426-36432. [PubMed: 15215247]

34. Le Goffic R, Pothlichet J, Vitour D, et al. Influenza A virus activates TLR3-dependent inflammatory and RIG-I-dependent antiviral responses in human lung epithelial cells. J Immunol 2007;178:33683372. [PubMed: 17339430]

35. Wright JR. Immunoregulatory functions of surfactant proteins. Nat Rev Immunol 2005;5:58-68. [PubMed: 15630429]

36. Branger J, Florquin S, Knapp S, et al. LPS-binding protein-deficient mice have an impaired defense against Gram-negative but not Gram-positive pneumonia. Int Immunol 2004;16:1605-1611. [PubMed: 15452020]

37. Frevert CW, Matute-Bello G, Skerrett SJ, et al. Effect of CD14 blockade in rabbits with Escherichia coli pneumonia and sepsis. J Immunol 2000;164:5439-5445. [PubMed: 10799910]

38. Jia HP, Kline JN, Penisten A, et al. Endotoxin responsiveness of human airway epithelia is limited by low expression of MD-2. Am J Physiol Lung Cell Mol Physiol 2004;287:L428-L437. [PubMed: 15121639]

39. Reading PC, Morey LS, Crouch EC, Anders EM. Collectin-mediated antiviral host defense of the lung: evidence from influenza virus infection of mice. J Virol 1997;71:8204-8212. [PubMed: 9343171]

40. Thomas-Rudolph D, Du Clos TW, Snapper CM, Mold C. C-reactive protein enhances immunity to Streptococcus pneumoniae by targeting uptake to Fc \{gamma $\}$ R on dendritic cells. J Immunol 2007;178:7283-7291. [PubMed: 17513778]

41. Skerrett SJ, Liggitt HD, Hajjar AM, Wilson CB. Myeloid differentiation factor 88 is essential for pulmonary host defense against Pseudomonas aeruginosa but not Staphylococcus aureus. J Immunol 2004;172:3377-3381. [PubMed: 15004134]

42. Jeyaseelan S, Young SK, Yamamoto M, et al. Toll/IL-1R domain-containing adaptor protein (TIRAP) is a critical mediator of antibacterial defense in the lung against Klebsiella pneumoniae but not Pseudomonas aeruginosa. J Immunol 2006;177:538-547. [PubMed: 16785551]

43. Li Q, Verma IM. NF-kappaB regulation in the immune system. Nat Rev Immunol 2002;2:725-734. [PubMed: 12360211][Erratum, Nat Rev Immunol 2002;2:975.]

44. Alcamo EA, Mizgerd JP, Horwitz BH, et al. Targeted mutation of TNF receptor 1 rescues the RelAdeficient mouse and reveals a critical role for NF-kB in leukocyte recruitment. J Immunol 2001;167:1592-1600. [PubMed: 11466381]

45. Quinton LJ, Jones MR, Simms BT, et al. Functions and regulation of NF-kappaB RelA during pneumococcal pneumonia. J Immunol 2007;178:1896-1903. [PubMed: 17237440]

46. Honda K, Takaoka A, Taniguchi T. Type I interferon gene induction by the interferon regulatory factor family of transcription factors. Immunity 2006;25:349-360. [PubMed: 16979567][Erratum, Immunity 2006;25:849.]

47. Kiyotani K, Sakaguchi T, Kato A, Nagai Y, Yoshida T. Paramyxovirus Sendai virus V protein counteracts innate virus clearance through IRF-3 activation, but not via interferon, in mice. Virology 2007;359:82-91. [PubMed: 17027894]

48. Gardai SJ, Xiao YQ, Dickinson M, et al. By binding SIRPalpha or calreticulin/CD91, lung collectins act as dual function surveillance molecules to suppress or enhance inflammation. Cell 2003;115:1323. [PubMed: 14531999]

49. Takabayshi K, Corr M, Hayashi T, et al. Induction of a homeostatic circuit in lung tissue by microbial compounds. Immunity 2006;24:475-487. [PubMed: 16618605] 
50. Jahnsen FL, Strickland DH, Thomas JA, et al. Accelerated antigen sampling and transport by airway mucosal dendritic cells following inhalation of a bacterial stimulus. J Immunol 2006;177:5861-5867. [PubMed: 17056510]

51. Cao W, Liu YJ. Innate immune functions of plasmacytoid dendritic cells. Curr Opin Immunol 2007;19:24-30. [PubMed: 17113765]

52. Smit JJ, Rudd BD, Lukacs NW. Plasmacytoid dendritic cells inhibit pulmonary immunopathology and promote clearance of respiratory syncytial virus. J Exp Med 2006;203:1153-1159. [PubMed: 16682497]

53. Koerner I, Kochs G, Kalinke U, Weiss S, Staeheli P. Protective role of beta interferon in host defense against influenza A virus. J Virol 2007;81:2025-2030. [PubMed: 17151098]

54. Mizgerd JP. Molecular mechanisms of neutrophil recruitment elicited by bacteria in the lungs. Semin Immunol 2002;14:123-132. [PubMed: 11978084]

55. Christopher MJ, Link DC. Regulation of neutrophil homeostasis. Curr Opin Hematol 2007;14:3-8. [PubMed: 17133093]

56. Poynter ME, Irvin CG, Janssen-Heininger YM. A prominent role for airway epithelial NF-kappa B activation in lipopolysaccharide-induced airway inflammation. J Immunol 2003;170:6257-6265. [PubMed: 12794158]

57. Skerrett SJ, Liggitt HD, Hajjar AM, Ernst RK, Miller SI, Wilson CB. Respiratory epithelial cells regulate lung inflammation in response to inhaled endotoxin. Am J Physiol Lung Cell Mol Physiol 2004;287:L143-L152. [PubMed: 15047567]

58. Diamond G, Legarda D, Ryan LK. The innate immune response of the respiratory epithelium. Immunol Rev 2000;173:27-38. [PubMed: 10719665]

59. Gomez MI, Lee A, Reddy B, et al. Staphylococcus aureus protein A induces airway epithelial inflammatory responses by activating TNFR1. Nat Med 2004;10:842-848. [PubMed: 15247912]

60. Soong G, Reddy B, Sokol S, Adamo R, Prince A. TLR2 is mobilized into an apical lipid raft receptor complex to signal infection in airway epithelial cells. J Clin Invest 2004;113:1482-1489. [PubMed: 15146246]

61. Jones MR, Simms BT, Lupa MM, Kogan MS, Mizgerd JP. Lung NF-\{kappa\}B activation and neutrophil recruitment require IL-1 and TNF receptor signaling during pneumococcal pneumonia. $\mathrm{J}$ Immunol 2005;175:7530-7535. [PubMed: 16301661]

62. Mizgerd JP, Spieker MR, Doerschuk CM. Early response cytokines and innate immunity: essential roles for TNF receptor 1 and type I L1-1 receptor during Escherichia coli pneumonia in mice. J Immunol 2001;166:4042-4048. [PubMed: 11238652]

63. Mizgerd JP, Lupa MM, Hjoberg J, et al. Roles for early response cytokines during Escherichia coli pneumonia revealed by mice with combined deficiencies of all signaling receptors for TNF and IL-1. Am J Physiol Lung Cell Mol Physiol 2004;286:L1302-L1310. [PubMed: 14966082]

64. Ye P, Rodriguez FH, Kanaly S, et al. Requirement of interleukin 17 receptor signaling for lung CXC chemokine and granulocyte colony-stimulating factor expression, neutrophil recruitment, and host defense. J Exp Med 2001;194:519-527. [PubMed: 11514607]

65. Happel KI, Dubin PJ, Zheng M, et al. Divergent roles of IL-23 and IL-12 in host defense against Klebsiella pneumoniae. J Exp Med 2005;202:761-769. [PubMed: 16157683]

66. Michel ML, Keller AC, Paget C, et al. Identification of an IL-17-producing NK1.1(neg) iNKT cell population involved in airway neutrophilia. J Exp Med 2007;204:995-1001. [PubMed: 17470641]

67. Liang SC, Tan XY, Luxenberg DP, et al. Interleukin (IL)-22 and IL-17 are coexpressed by Th17 cells and cooperatively enhance expression of antimicrobial peptides. J Exp Med 2006;203:2271-2279. [PubMed: 16982811]

68. Tateda K, Moore TA, Deng JC, et al. Early recruitment of neutrophils determines subsequent T1/T2 host responses in a murine model of Legionella pneumophila pneumonia. J Immunol 2001;166:33553361. [PubMed: 11207291]

69. Sun K, Salmon SL, Lotz SA, Metzger DW. Interleukin-12 promotes gamma interferon-dependent neutrophil recruitment in the lung and improves protection against respiratory Streptococcus pneumoniae infection. Infect Immun 2007;75:1196-1202. [PubMed: 17210665] 
70. Jaillon S, Peri G, Delneste Y, et al. The humoral pattern recognition receptor PTX3 is stored in neutrophil granules and localizes in extracellular traps. J Exp Med 2007;204:793-804. [PubMed: 17389238]

71. Cheng DS, Han W, Chen SM, et al. Airway epithelium controls lung inflammation and injury through the NF-\{kappa\}B pathway. J Immunol 2007;178:6504-6513. [PubMed: 17475880]

72. Bauer TT, Ewig S, Rodloff AC, Müller EE. Acute respiratory distress syndrome and pneumonia: a comprehensive review of clinical data. Clin Infect Dis 2006;43:748-756. [PubMed: 16912951]

73. Klesney-Tait J, Turnbull IR, Colonna M. The TREM receptor family and signal integration. Nat Immunol 2006;7:1266-1273. [PubMed: 17110943]

74. Gibot S, Cravoisy A, Levy B, Bene MC, Faure G, Bollaert P-E. Soluble triggering receptor expressed on myeloid cells and the diagnosis of pneumonia. N Engl J Med 2004;350:451-458. [PubMed: 14749453]

75. Gibot S, Alauzet C, Massin F, et al. Modulation of the triggering receptor expressed on myeloid cells-1 pathway during pneumonia in rats. J Infect Dis 2006;194:975-983. [PubMed: 16960786]

76. Confalonieri M, Urbino R, Potena A, et al. Hydrocortisone infusion for severe community-acquired pneumonia: a preliminary randomized study. Am J Respir Crit Care Med 2005;171:242-248. [PubMed: 15557131]

77. Rañó A, Agustí C, Sibila O, Torres A. Associated inflammatory response in pneumonia: role of adjunctive therapy with glucocorticoids. Curr Opin Infect Dis 2006;19:179-184. [PubMed: 16514343]

78. de Jong MD, Simmons CP, Thanh TT, et al. Fatal outcome of human influenza A (H5N1) is associated with high viral load and hypercytokinemia. Nat Med 2006;12:1203-1207. [PubMed: 16964257]

79. Kobasa D, Jones SM, Shinya K, et al. Aberrant innate immune response in lethal infection of macaques with the 1918 influenza virus. Nature 2007;445:319-323. [PubMed: 17230189]

80. Tumpey TM, Garcia-Sastre A, Taubenberger JK, et al. Pathogenicity of influenza viruses with genes from the 1918 pandemic virus: functional roles of alveolar macrophages and neutrophils in limiting virus replication and mortality in mice. J Virol 2005;79:14933-14944. [PubMed: 16282492]

81. Szretter KJ, Gangappa S, Lu X, et al. Role of host cytokine responses in the pathogenesis of avian H5N1 influenza viruses in mice. J Virol 2007;81:2736-2744. [PubMed: 17182684]

82. Mizgerd JP, Lupa MM, Kogan MS, Warren HB, Kobzik L, Topulos GP. Nuclear factor-kB p50 limits inflammation and prevents lung injury during Escherichia coli pneumonia. Am J Respir Crit Care Med 2003;168:810-817. [PubMed: 12857723]

83. Deng JC, Cheng G, Newstead MW, et al. Sepsis-induced suppression of lung innate immunity is mediated by IRAK-M. J Clin Invest 2006;116:2532-2542. [PubMed: 16917541]

84. Nakahira K, Kim HP, Geng XH, et al. Carbon monoxide differentially inhibits TLR signaling pathways by regulating ROS-induced trafficking of TLRs to lipid rafts. J Exp Med 2006;203:23772389. [PubMed: 17000866]

85. Hashiba T, Suzuki M, Nagashima Y, et al. Adenovirus-mediated transfer of heme oxygenase-1 cDNA attenuates severe lung injury induced by the influenza virus in mice. Gene Ther 2001;8:1499-1507. [PubMed: 11593363]

86. Tsuburai T, Kaneko T, Nagashima Y. Pseudomonas aeruginosa-induced neutrophilic lung inflammation is attenuated by adenovirus-mediated transfer of the heme oxygenase $1 \mathrm{cDNA}$ in mice. Hum Gene Ther 2004;15:273-285. [PubMed: 15018736]

87. Fredenburgh LE, Baron RM, Carvajal IM, et al. Absence of heme oxygenase-1 expression in the lung parenchyma exacerbates endotoxin-induced acute lung injury and decreases surfactant protein-B levels. Cell Mol Biol (Noisy-le-grand) 2005;51:513-520. [PubMed: 16309574]

88. Holland SM, DeLeo FR, Elloumi HZ, et al. STAT3 mutations in the hyper-IgE syndrome. N Engl J Med 2007;357:1608-1619. [PubMed: 17881745]

89. Severgnini M, Takahashi S, Rozo LM, et al. Activation of the STAT pathway in acute lung injury. Am J Physiol Lung Cell Mol Physiol 2004;286:L1282-L1292. [PubMed: 14729509]

90. Matsukawa A, Kudo S, Maeda T, et al. Stat3 in resident macrophages as a repressor protein of inflammatory response. J Immunol 2005;175:3354-3359. [PubMed: 16116228] 
91. Greenberger MJ, Strieter RM, Kunkel SL, Danforth JM, Goodman RE, Standiford TJ. Neutralization of IL-10 increases survival in a murine model of Klebsiella pneumonia. J Immunol 1995;155:722729. [PubMed: 7608550]

92. van der Poll T, Marchant A, Keogh CV, Goldman M, Lowry SF. Interleukin-10 impairs host defense in murine pneumococcal pneumonia. J Infect Dis 1996;174:994-1000. [PubMed: 8896500]

93. Kurahashi K, Kajikawa O, Sawa T, et al. Pathogenesis of septic shock in Pseudomonas aeruginosa pneumonia. J Clin Invest 1999;104:743-750. [PubMed: 10491409]

94. Wang E, Bergeron Y, Bergeron MG. Ceftriaxone pharmacokinetics in interleukin-10-treated murine pneumococcal pneumonia. J Antimicrob Chemother 2005;55:721-726. [PubMed: 15772139]

95. Matsuzaki Y, Xu Y, Ikegami Me, et al. Stat3 is required for cytoprotection of the respiratory epithelium during adenoviral infection. J Immunol 2006;177:527-537. [PubMed: 16785550]

96. Jones MR, Quinton LJ, Simms BT, Lupa MM, Kogan MS, Mizgerd JP. Roles of interleukin-6 in activation of STAT proteins and recruitment of neutrophils during Escherichia coli pneumonia. J Infect Dis 2006;193:360-369. [PubMed: 16388483]

97. Hashimoto K, Graham BS, Geraci MW, et al. Signaling through the prostaglandin I2 receptor IP protects against respiratory syncytial virus-induced illness. J Virol 2004;78:10303-10309. [PubMed: 15367596]

98. Zhou W, Hashimoto K, Goleniewska K, et al. Prostaglandin I2 analogs inhibit proinflammatory cytokine production and T cell stimulatory function of dendritic cells. J Immunol 2007;178:702-710. [PubMed: 17202330]

99. Serhan CN. Resolution phase of inflammation: novel endogenous anti-inflammatory and proresolving lipid mediators and pathways. Annu Rev Immunol 2007;25:101-137. [PubMed: 17090225]

100. de Roux A, Ewig S, García E, et al. Mixed community-acquired pneumonia in hospitalised patients. Eur Respir J 2006;27:795-800. [PubMed: 16585087]

101. Weber DJ, Rutala WA, Sickbert-Bennett EE, Samsa GP, Brown V, Niederman MS. Microbiology of ventilator-associated pneumonia compared with that of hospital-acquired pneumonia. Infect Control Hosp Epidemiol 2007;28:825-831. [PubMed: 17564985]

102. Webster RG, Govorkova EA. H5N1 influenza — continuing evolution and spread. N Engl J Med 2006;355:2174-2147. [PubMed: 17124014]

103. Beiter K, Wartha F, Albiger B, Normark S, Zychlinsky A, Henriques-Normark B. An endonuclease allows Streptococcus pneumoniae to escape from neutrophil extracellular traps. Curr Biol 2006;16:401-407. [PubMed: 16488875]

104. Pichlmair A, Schulz O, Tan CP, et al. RIG-I-mediated antiviral responses to single-stranded RNA bearing 5'-phosphates. Science 2006;314:997-1001. [PubMed: 17038589]

105. Kochs G, Koerner I, Thiel L, et al. Properties of H7N7 influenza A virus strain SC35M lacking interferon antagonist NS1 in mice and chickens. J Gen Virol 2007;88:1403-1409. [PubMed: 17412966]

106. Wu L, Estrada O, Zaborina O, et al. Recognition of host immune activation by Pseudomonas aeruginosa. Science 2005;309:774-777. [PubMed: 16051797]

107. Meduri GU, Kanangat S, Stefan J, Tolley E, Schaberg D. Cytokines IL-1 $\beta$, IL-6, and TNF- $\alpha$ enhance in vitro growth of bacteria. Am J Respir Crit Care Med 1999;160:961-967. [PubMed: 10471625]

108. Lee JH, Del Sorbo L, Khine AA, et al. Modulation of bacterial growth by tumor necrosis factoralpha in vitro and in vivo. Am J Respir Crit Care Med 2003;168:1462-1470. [PubMed: 12958055]

109. Tal G, Mandelberg A, Dalal I, et al. Association between common Toll-like receptor 4 mutations and severe respiratory syncytial virus disease. J Infect Dis 2004;189:2057-2063. [PubMed: 15143473]

110. Hawn TR, Verbon A, Janer M, Zhao LP, Beutler B, Aderem A. Toll-like receptor 4 polymorphisms are associated with resistance to Legionnaires' disease. Proc Natl Acad Sci U S A 2005;102:24872489. [PubMed: 15699327]

111. Hawn TR, Verbon A, Lettinga KD, et al. A common dominant TLR5 stop codon polymorphism abolishes flagellin signaling and is associated with susceptibility to Legionnaires' disease. J Exp Med 2003;198:1563-1572. [PubMed: 14623910] 
112. Inoue Y, Shimojo N, Suzuki Y, et al. CD14 -550 C/T, which is related to the serum level of soluble $\mathrm{CD} 14$, is associated with the development of respiratory syncytial virus bronchiolitis in the Japanese population. J Infect Dis 2007;195:1618-1624. [PubMed: 17471431]

113. Ku CL, von Bernuth H, Picard C, et al. Selective predisposition to bacterial infections in IRAK-4deficient children: IRAK-4-dependent TLRs are otherwise redundant in protective immunity. J Exp Med 2007;204:2407-2422. [PubMed: 17893200]

114. Ku CL, Picard C, Erdös M, et al. IRAK4 and NEMO mutations in otherwise healthy children with recurrent invasive pneumococcal disease. J Med Genet 2007;44:16-23. [PubMed: 16950813]

115. Khor CC, Chapman SJ, Vannberg FO, et al. A Mal functional variant is associated with protection against invasive pneumococcal disease, bacteremia, malaria and tuberculosis. Nat Genet 2007;39:523-528. [PubMed: 17322885]

116. Roy S, Knox K, Segal S, et al. MBL genotype and risk of invasive pneumococcal disease: a casecontrol study. Lancet 2002;359:1569-1573. [PubMed: 12047967]

117. Gomi K, Tokue Y, Kobayashi T, et al. Mannose-binding lectin gene polymorphism is a modulating factor in repeated respiratory infections. Chest 2004;126:95-99. [PubMed: 15249448]

118. Gong MN, Zhou W, Williams PL, Thompson BT, Pothier L, Christiani DC. Polymorphisms in the mannose binding lectin-2 gene and acute respiratory distress syndrome. Crit Care Med 2007;35:4856. [PubMed: 17133182]

119. Jönsson G, Truedsson L, Sturfelt G, Oxelius VA, Braconier JH, Sjöholm AG. Hereditary C2 deficiency in Sweden: frequent occurrence of invasive infection, atherosclerosis, and rheumatic disease. Medicine (Baltimore) 2005;84:23-34. [PubMed: 15643297]

120. Lahti M, Lofgren J, Marttila R, et al. Surfactant protein D gene polymorphism associated with severe respiratory syncytial virus infection. Pediatr Res 2002;51:696-699. [PubMed: 12032263]

121. Löfgren J, Rämet M, Renko M, Marttila R, Hallman M. Association between surfactant protein A gene locus and severe respiratory syncytial virus infection in infants. J Infect Dis 2002;185:283289. [PubMed: 11807709]

122. Adamzik M, Frey UH, Rieman K, et al. Insertion/deletion polymorphism in the promoter of NFKB1 influences severity but not mortality of acute respiratory distress syndrome. Intensive Care Med 2007;33:1199-1203. [PubMed: 17468848]

123. Chapman SJ, Khor CC, Vannberg FO, et al. I\{kappa\}B genetic polymorphisms and invasive pneumococcal disease. Am J Respir Crit Care Med 2007;176:181-187. [PubMed: 17463416]

124. Zhai R, Zhou W, Gong MN, et al. Inhibitor kappaB-alpha haplotype GTC is associated with susceptibility to acute respiratory distress syndrome in Caucasians. Crit Care Med 2007;35:893898. [PubMed: 17235259]

125. Schaaf B, Rupp J, Müller-Steinhardt M, et al. The interleukin-6 -174 promoter polymorphism is associated with extrapulmonary bacterial dissemination in Streptococcus pneumoniae infection. Cytokine 2005;31:324-328. [PubMed: 16005243]

126. Wattanathum A, Manocha S, Groshaus H, Russell JA, Walley KR. Interleukin-10 haplotype associated with increased mortality in critically ill patients with sepsis from pneumonia but not in patients with extrapulmonary sepsis. Chest 2005;128:1690-1698. [PubMed: 16162776]

127. Gong MN, Thompson BT, Williams PL. Interleukin-10 polymorphism in position -1082 and acute respiratory distress syndrome. Eur Respir J 2006;27:674-681. [PubMed: 16585075]

128. Yasuda H, Okinaga S, Yamaya M, et al. Association of susceptibility to the development of pneumonia in the older Japanese population with haem oxygenase-1 gene promoter polymorphism. J Med Genet 2006;43:e17. [PubMed: 16582079]

129. Chanock SJ, Manolio T, Boehnke M, et al. Replicating genotype-phenotype associations. Nature 2007;447:655-660. [PubMed: 17554299]

130. Rosenzweig SD, Holland SM. Phagocyte immunodeficiencies and their infections. J Allergy Clin Immunol 2004;113:620-626. [PubMed: 15100664]

131. Casanova JL, Abel L. Primary immunodeficiencies: a field in its infancy. Science 2007;317:617619. [PubMed: 17673650] 


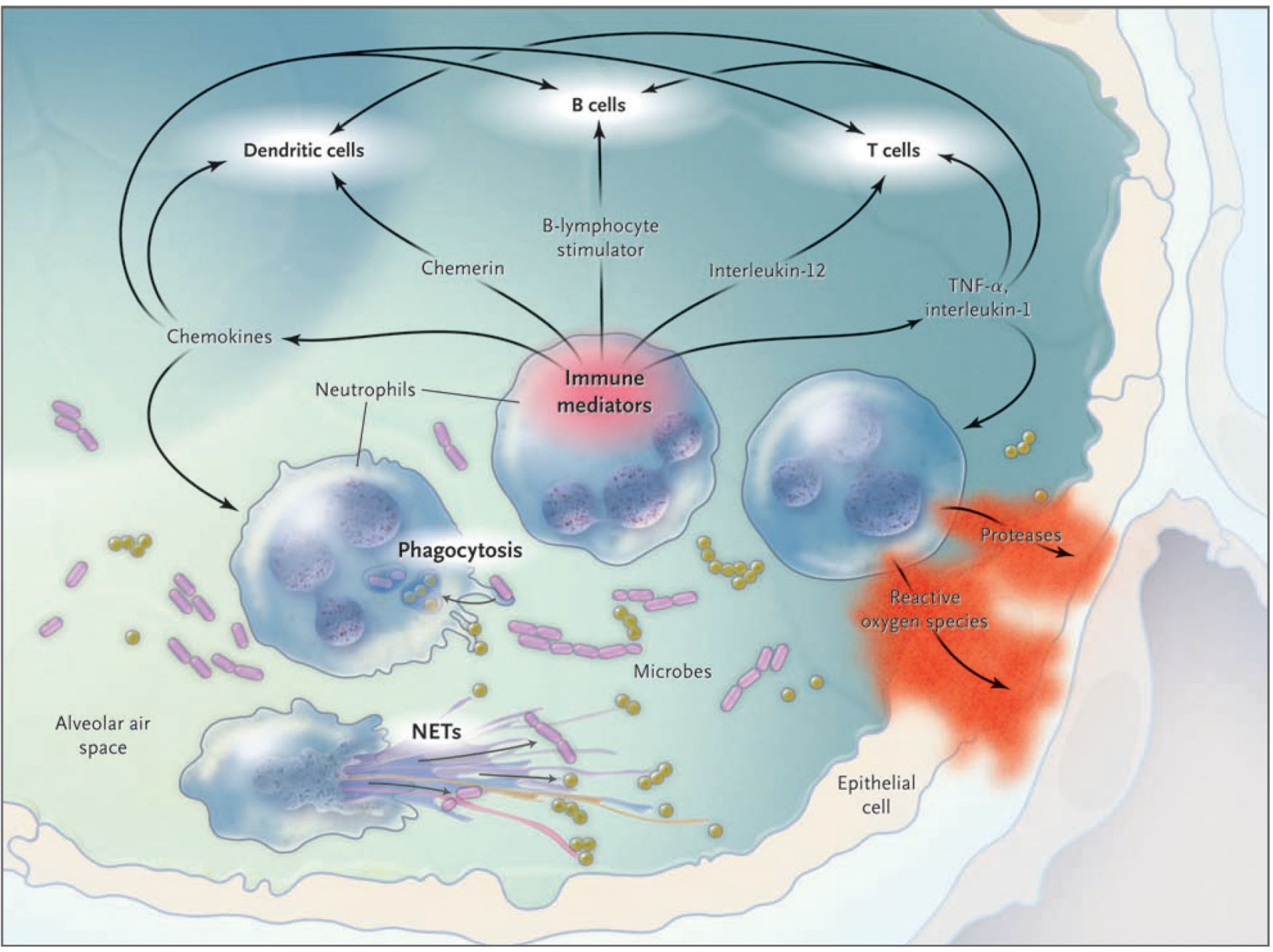

Figure 1. Neutrophils and Lung Infection

Neutrophils are effector cells of innate immunity, killing microbes using phagocytosis and neutrophil extracellular traps (NETs). Neutrophils also generate a variety of immune mediators to direct immune responses, influencing other cells of innate and adaptive immunity. Finally, neutrophils damage tissues, with products such as proteases and reactive oxygen species injuring cells and digesting matrix. TNF denotes tumor necrosis factor. 


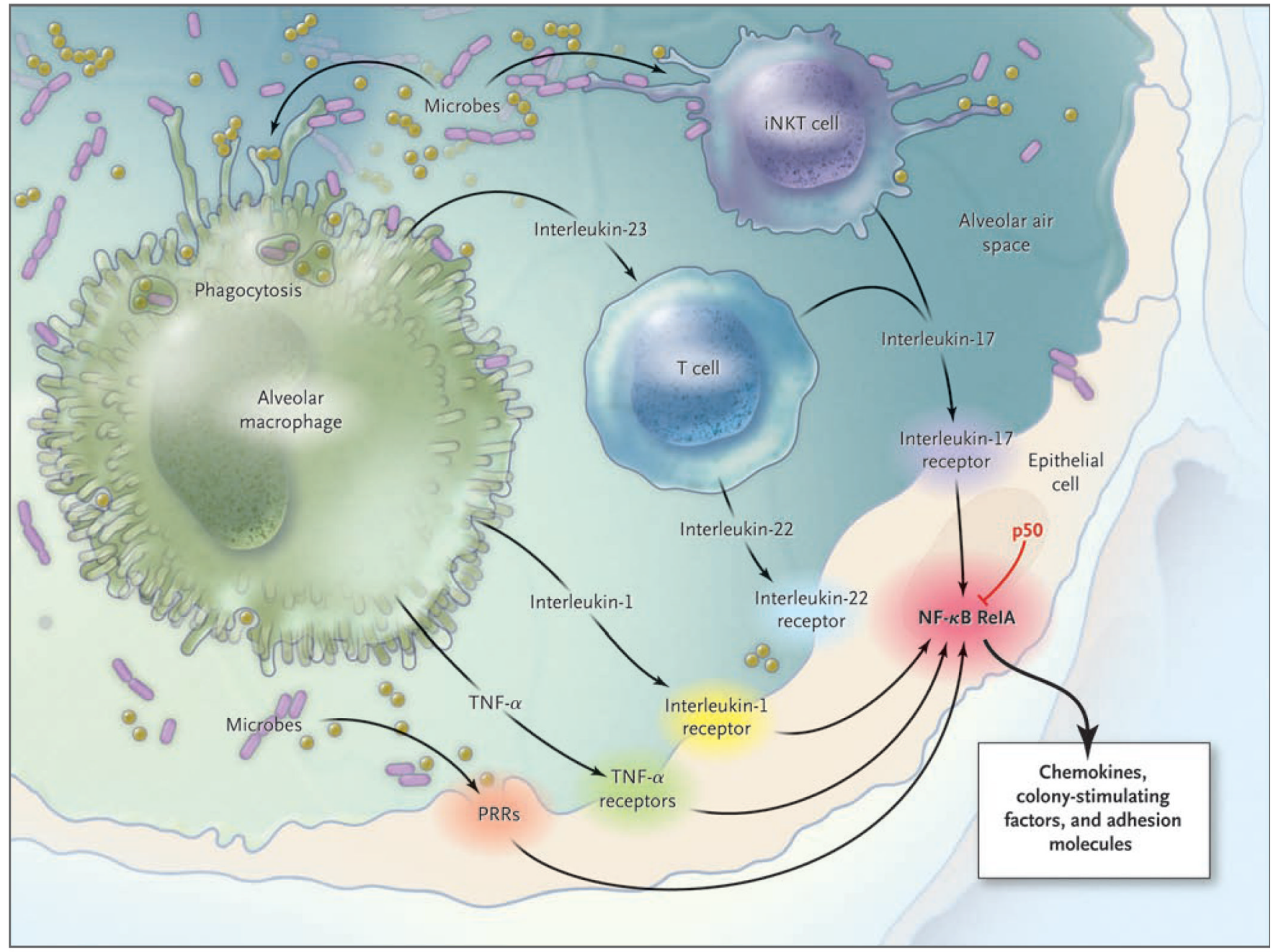

Figure 2. The Epithelial Interface and Lung Infection

Activation of the epithelial cells forming an interface between the air spaces and the body induces the expression of molecules recruiting neutrophils as innate immunity reinforcements. Epithelial cells recognize some microbes directly through pattern-recognition receptors (PRRs). Alveolar macrophages recognizing microbes activate epithelial cells directly and through T-cell intermediates. Invariant natural killer T (iNKT) cells recognizing microbes can also activate epithelial cells. These diverse activation pathways converge on nuclear factor $\kappa \mathrm{B}(\mathrm{NF}-\mathrm{\kappa B})$ transcription factors in the epithelial cell, with RelA responsible for inducing and p50 responsible for regulating the expression of proinflammatory mediators, including neutrophil chemokines, colony-stimulating factors, and adhesion molecules. TNF denotes tumor necrosis factor. 
Table 1

Pattern-Recognition Receptors Implicated in Acute Lower Respiratory Tract Infections.

\begin{tabular}{|c|c|c|}
\hline Receptor & Microbial Ligands & References \\
\hline \multicolumn{3}{|l|}{ Transmembrane } \\
\hline \multicolumn{3}{|l|}{ TLRs (toll-like receptors) } \\
\hline TLR2 & Peptidoglycans from bacteria & Knapp et al. ${ }^{15}$ \\
\hline TLR3 & Respiratory syncytial virus & Rudd et al. ${ }^{16}$ \\
\hline TLR4 & $\begin{array}{l}\text { Lipopolysaccharides from gram-negative bacteria, } \\
\text { fusion proteins from respiratory syncytial virus, } \\
\text { pneumolysin from Streptococcus pneumoniae }\end{array}$ & $\underset{19}{\text { Branger et al.., }}{ }^{17}$ Kurt-Jones et al., ${ }^{18}$ Malley et al. \\
\hline TLR5 & Flagellin from bacteria & Feuillet et al. ${ }^{20}$ \\
\hline TLR9 & CpG DNA from bacteria & Albiger et al. ${ }^{21}$ \\
\hline $\begin{array}{l}\text { MARCO (macrophage receptor with collagenous } \\
\text { structure) }\end{array}$ & S. pneumoniae & Arredouani et al. ${ }^{22}$ \\
\hline SRA-I and SRA-II (scavenger receptors AI and AII) & S. pneumoniae & Arredouani et al. ${ }^{23}$ \\
\hline Dectin-1 & $\beta$-glucan of fungi, Pneumocystis carinii & Steele et al. ${ }^{24,25}$ \\
\hline DC-SIGN ${ }^{*}$ & S. pneumoniae & Koppel et al. ${ }^{26}$ \\
\hline FPR (formyl peptide receptor) & $\mathrm{N}$-formylated peptides of bacteria & Fillion et al. $^{27}$ \\
\hline MR (mannose receptor) & P. carinii & Tachado et al. ${ }^{28}$ \\
\hline NKp46 (natural killer cell p46) & $\begin{array}{l}\text { Hemagglutinin from influenza viruses, } \\
\text { hemagglutinin neuraminidase from parainfluenza } \\
\text { viruses }\end{array}$ & Mandelboim et al., ${ }^{29}$ Gazit et al. ${ }^{30}$ \\
\hline \multicolumn{3}{|l|}{ Cytosolic } \\
\hline Naip5 (neuronal apoptosis-inhibiting protein 5) & Legionella pneumophila & Wright et al. ${ }^{31}$ \\
\hline $\operatorname{Ipaf}^{\dagger}$ & L. pneumophila & Amer et al. ${ }^{32}$ \\
\hline $\begin{array}{l}\text { Nod1 and Nod2 (nucleotide oligomerization domains } 1 \\
\text { and 2) }\end{array}$ & Peptidoglycan components from bacteria & Opitz et al. ${ }^{33}$ \\
\hline RIG-I (retinoic acid-inducible gene I) & Influenza virus RNA & Le Goffic et al. ${ }^{34}$ \\
\hline \multicolumn{3}{|l|}{ Extracellular } \\
\hline SP-A and SP-D (surfactant proteins A and D) & $\begin{array}{l}\text { Influenza virus, respiratory syncytial virus, } \\
\text { gramnegative bacteria, gram-positive bacteria }\end{array}$ & Wright ${ }^{35}$ \\
\hline LBP (lipopolysaccharide-binding protein) & Lipopolysaccharides from gram-negative bacteria & Branger et al. ${ }^{36}$ \\
\hline CD14 & Lipopolysaccharides from gram-negative bacteria & Frevert et al. ${ }^{37}$ \\
\hline MD-2 & Lipopolysaccharides from gram-negative bacteria & Jia et al. ${ }^{38}$ \\
\hline PTX3 (pentraxin 3) & Aspergillus fumigatus & Garlanda et al. ${ }^{10}$ \\
\hline MBL (mannose-binding lectin) & Mannosylated moieties on microbes & Reading et al. ${ }^{39}$ \\
\hline CRP (C-reactive protein) & Phosphocholine on S. pneumoniae & Thomas-Rudolph et al. ${ }^{40}$ \\
\hline Complement & Microbial surfaces & Mold et al. ${ }^{11}$ \\
\hline
\end{tabular}

* DC-SIGN denotes dendritic-cell-specific ICAM-3-grabbing nonintegrim (ICAM denotes intercellular adhesion molecule).

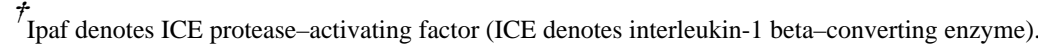


Table 2

Genetic Polymorphisms Associated with Lung Infection Outcomes.

\begin{tabular}{|c|c|c|}
\hline Gene Product & Association & References \\
\hline \multicolumn{3}{|l|}{ Initiating and amplifying mechanisms } \\
\hline \multicolumn{3}{|l|}{ TLRs (toll-like receptors) } \\
\hline TLR4 & $\begin{array}{l}\text { Legionella pneumonia, severe respiratory } \\
\text { syncytial virus infection }\end{array}$ & Tal et al., ${ }^{109}$ Hawn et al. ${ }^{110}$ \\
\hline TLR5 & Legionella pneumonia & Hawn et al. ${ }^{111}$ \\
\hline CD14 & Respiratory syncytial virus bronchiolitis & Inoue et al. ${ }^{112}$ \\
\hline IRAK-4 (interleukin-1 receptor-associated kinase 4) & $\begin{array}{l}\text { Bacterial infections, particularly pneumococcal } \\
\text { Infection }\end{array}$ & Ku et al. ${ }^{113}$ \\
\hline NEMO - NF- $\mathrm{KB}$ activation & Recurrent invasive pneumococcal disease & Ku et al. ${ }^{114}$ \\
\hline $\begin{array}{l}\text { Mal (MyD88 adaptor-like protein) — toll-like receptor } \\
\text { signaling }\end{array}$ & Invasive pneumococcal disease & Khor et al. ${ }^{115}$ \\
\hline MBL (mannose-binding lectin) & $\begin{array}{l}\text { Invasive pneumococcal disease, recurrent } \\
\text { respiratory infections, acute lung injury }\end{array}$ & Roy et al., ${ }^{116}$ Gomi et al., ${ }^{117}$ Gong et al. ${ }^{118}$ \\
\hline Complement $\mathrm{C} 2$ & $\begin{array}{l}\text { Invasive pneumococcal disease and recurrent } \\
\text { Pneumonias }\end{array}$ & Jönsson et al. ${ }^{119}$ \\
\hline SP-A, SP-D (surfactant proteins A and D) & Severe respiratory syncytial virus infection & Lahti et al., ${ }^{120}$ Löfgren et al. ${ }^{121}$ \\
\hline \multicolumn{3}{|l|}{ Regulating mechanisms } \\
\hline NF-кB p50 & Acute lung injury & Adamzik et al. ${ }^{122}$ \\
\hline IкB- $\alpha$ & Invasive pneumococcal disease, acute lung injury & Chapman et al., ${ }^{123}$ Zhai et al. ${ }^{124}$ \\
\hline \multicolumn{3}{|l|}{ Interleukins } \\
\hline Interleukin-6 & Invasive pneumococcal disease & Schaaf et al. ${ }^{125}$ \\
\hline Interleukin-10 & Pneumonia outcomes and acute lung Injury & Wattanathum et al., ${ }^{126}$ Gong et al. ${ }^{127}$ \\
\hline HO-1 (heme oxygenase-1) & Pneumonia susceptibility & Yasuda et al. ${ }^{128}$ \\
\hline STAT3 (signal transducer and activator of transcription 3) & $\begin{array}{l}\text { Hyper-IgE syndrome - recurrent severe lung } \\
\text { infections }\end{array}$ & Holland et al. ${ }^{88}$ \\
\hline
\end{tabular}

NEMO denotes NF- $\mathrm{kB}$ essential modulator, and NF- $\mathrm{\kappa B}$ nuclear factor $\kappa \mathrm{B}$. 